\title{
Influence of Utilizing Milk Marketing Information through Mobile Phones on Milk Yield among Smallholder Dairy Farmers in Njoro Sub-County, Kenya
}

\author{
Josephat W 0 Smollo ${ }^{1 *}$, Benson M Githaiga ${ }^{2}$ and Maximillah Barasa ${ }^{2}$ \\ ${ }^{1}$ Department of Applied Community Development Studies, Egerton University, Kenya \\ ${ }^{2}$ Department of Biological Sciences, Egerton University, Kenya
}

Submission: March 06, 2017; Published: April 12, 2017

"Corresponding author: Josephat W O Smollo, Department of Applied Community Development Studies, Egerton University, Kenya, Email: josmollochi@yahoo.com

\begin{abstract}
Dairy cattle farming in Kenya contribute 3.5\% of the national Gross Domestic Product (GDP); and provide income, employment and food to 1.6 million smallholder dairy farmers. The major constraint in the dairy industry in Njoro Sub-County is inadequate utilization of milk marketing information by smallholder dairy farmers with one of the consequences being low milk yield. Over 80 per cent of the smallholder dairy farmers and all the livestock extension officers in Njoro Sub-County own mobile phones.

This creates an opportunity for smallholder dairy farmers to utilize milk marketing information through mobile phones which remains under-exploited. The purpose of this study therefore, was to determine the influence of utilizing milk marketing information through mobile phones on milk yield among smallholder dairy farmers in Njoro Sub-County, Kenya. An ex post facto research was carried out to collect data from a sample of 106 smallholder dairy farmers selected by probability sampling from Njoro Division. A researcher administered questionnaire was used for data collection. Validity of the instruments was examined by supervisors and piloting was done in Mauche Division to determine the reliability of the tool. The null hypothesis was tested using Pearson's Correlation at $5 \%$ level of significance. The results revealed that there was a statistically significant correlation between utilizing milk marketing information and milk yield among smallholder dairy farmers. The study therefore recommended that for increased milk production to be realized in Njoro Sub-County, deliberate efforts should be made to improve utilization of milk marketing information from mobile phones.
\end{abstract}

Keywords: Influence; Utilizing; Milk marketing information; Mobile phones; Milk yield; Smallholder dairy farmers

Abbreviation: GDP: Gross Domestic Product; IFAD: International Fund for Agricultural Development; EAC: East African Community; COMESA: Common Market for Eastern and Southern Africa; PDLP: Provincial Director of Livestock Production; DLPO: District Livestock Production Officer; ITU: International Telecommunications Union; SMS: Short Messages

\section{Introduction}

Livestock production is an integral component of rural development; contributing towards enhanced agricultural productivity, improved rural livelihoods and ecological services [1]. Globally, there are about 300 million rural and peri-urban people depending upon livestock for their livelihoods. It is estimated that from 300 million livestock dependent inhabitants, 150 million are residing in developing countries [2]. In Kenya 1.6 million people are livestock dependent. The dairy sector accounts for about 3.8 percent of the national Gross Domestic Product (GDP) and 14 percent of agricultural GDP. It provides income, employment and food to over 22 million Kenyans [3].
The country's dairy cow population is approximated to be 7.6 million, the biggest in sub-Saharan Africa (International Fund for Agricultural Development [4]. Kenya's membership to the regional trade blocks provides preferential market access for milk products within them. The regional milk markets include the East African Community (EAC) and the Common Market for Eastern and Southern Africa (COMESA) [5]. Milk is a basic household commodity in Kenya and constitutes a big percentage of the breakfast budget for over 25 million Kenyans (Government of Kenya (GOK) [6]. The country produces 6.8 billion litres of milk per year valued at Kenya shillings (Kes) 110 billion against the annual potential milk 
production of 17.8 billion liters. The smallholder dairy farmers are the majority and produce over 80 percent of the milk (Ministry of Livestock Development, (MOLD) [7].

According to the Provincial Director of Livestock Production (PDLP), Rift Valley province, in year 2015 the province had a dairy herd population of about two million with an annual milk production of two billion litres. This amount fetched an income of Kes. 34.6 billion During that year. However, the province has a potential to produce five billion litres per year [8]. Furthermore in the year 2015, the District Livestock Production Officer (DLPO), Njoro SubCounty revealed that dairy production was the most prominent livestock enterprise in the Sub-County. The report further indicated that the Sub-County had a population of 10,300 smallholder dairy farmers. The Sub-County total cattle population is estimated at 40,000; out of which 33,000 are pure breeds and their crosses while 7,000 are zebu. The current total milk yield in the Sub-County is approximately 18.5 million liters per year. However, the Sub-County has a potential of producing over 39 million liters of milk per year, which remains unexploited [9].

Mobile phone services are increasing faster than fixed-line networks. In 2004 for example, there were over 940 million mobile phone users compared to 900 million fixed telephone lines around the world. In 2014, the world had over 6 billion while East Africa had over 75 million mobile phones in use (International Telecommunications Union (ITU) [10]. In 2004, there were 240,000 fixed telephone line subscribers and 2.8 million cellular mobile subscribers in Kenya. Today Kenya has about 29.2 million mobile phone subscribers compared to only 70,000 fixed lines. There are four mobile phone operators in Kenya namely; Safaricom, Airtel, Orange and $\mathrm{Yu}$ (Communications Commission of Kenya (CCK) [11]. The percentage of smallholder famers using mobile phones in Kenya stands at 65 percent (Kenya National Bureau of Statistics (KNBS). Over 8,240 (80 percent) of the 10,300 smallholder dairy farmers in Njoro Sub-County own mobile phones [9]. The mobile phone may be a powerful tool in dairy farming business. The smallholder dairy farmers can interact with experts and systems via calls or short messages (sms) made through mobile phones to access milk marketing information hence improving livestock productivity system.

Mobile phones link producers and consumers; and producers and marketing outlets. They enable producers and market outlets obtain critical information rapidly. By linking these groups directly and at low costs mobile phones may help to reduce milk marketing information gaps between producers and consumers hence improving market linkages. Access to rapid and low cost information help smallholder dairy farmers make better production and marketing decisions which influence milk output (National Farmers Information Service (NAFIS) [12].

Despite the development of dairy farming, expanding markets and commercializing of the dairy farm business in Njoro Sub-County; smallholder dairy farmers still face many constraints. The major problem is inadequate utilization of milk marketing information with one of the envisaged consequences being low milk yield due to low milk prices. Milk production in Njoro Sub-County is estimated at 18.5 million against the potential of 39 million liters per year, which remains unexploited. The Livestock officer to farmer ratio is low, at $1: 5,940$ and the transport situation in the study area is also poor. The result is low utilization of milk marketing information possibly due to poor access. Utilization of milk marketing information could be improved by mobile phone technology use since over 80 percent of the smallholder dairy farmers in Njoro Sub County own mobile phones. Mobile phones have been considered due to their wide network, affordability, timeliness and ease of use by over 8,240 smallholder dairy farmers in the study area $[9,13]$. The smallholder dairy farmers need essential information that would help them improve their marketing strategies and earn better profits from milk sales [14]. The information should be easily, timely and conveniently accessible to all the dairy farmers [15]. Mobile phones could act as a channel used to access milk marketing information by the smallholder dairy farmers who may utilize the same to influence milk production in Njoro Sub-County. Hence, the need for the study to determine the influence of utilizing milk marketing information from mobile phones on milk yield among smallholder dairy farmers in Njoro Sub-County.

\section{Methodology}

\section{Research design}

The study employed an ex post facto research design and was conducted in Njoro Sub-County, Nakuru County in Kenya. An ex post facto research serves to indicate that the research in question is conducted after variations in the independent variable have already been determined in the natural course of events Ary et al. [16].

\section{Study area}

The Sub-County occupies an area of $779.7 \mathrm{~km} 2$ and was divided into Njoro, Mauche, Mau Narok and Lare divisions. Njoro Sub-County stands at an altitude of $1,800 \mathrm{M}$ above sea level with temperatures ranging between $17-22^{\circ} \mathrm{C}$ while the average annual rainfall is $1,270 \mathrm{~mm}$ [17]. The Sub-County's population was estimated at 287,647 persons (Kenya National Bureau of Statistics (KNBS) [18] and 10,300 smallholder dairy farmers by 2014. Eighty percent $(80 \%)$ of the population in the Sub-County depends on smallholder dairy production for their livelihood and dairy farming contributes over 85 per cent of the household income.

\section{Population}

The study's target population was the 2,800 smallholder dairy farmers in Njoro division that was purposively selected. This population owned mobile phones and used the devices to access animal husbandry information from livestock extension staff.

\section{Sampling procedure/sample selection}

Njoro division was purposively chosen for sampling out of the four divisions in Njoro Sub-County because it has the largest number of smallholder dairy farmers. The four locations of Njoro, Nessuit, Mukungugu and Kihingo in Njoro division were proportionately 
represented in the sample as in the divisional accessible population. Probability sampling technique was then used to select a sample of 106 respondents to be involved in the study from a sample frame of smallholder dairy farmers who use mobile phones to get dairy information from extension staff in Njoro division.

\section{Sample size calculation}

The following formula was used to determine the sample size where the population is known [19]. $n=N C 2 C 2=(N-1) 2$ Where; $\mathrm{n}=$ sample size; $\mathrm{N}=$ population size $\mathrm{e}=$ margin of error which is fixed between $2-5 \% \mathrm{C}=$ Coefficient of variation which is $\leq 30 \%$.

$n=2,800(0.21) 2(0.21) 2+=(2,800-1)(0.02) 2 n=106 ;$ Sample size $(n)=106$ respondents.

\section{Data collection}

Structured questionnaires used in the study were developed by the researcher with input from experts from the Department of Applied Community Development Studies at Egerton University. The researcher administered questionnaires were used to collect data from the sampled smallholder dairy farmers. The questionnaires were used by the researcher to ask each respondent the same questions in the same way and ensure collection of high quality data [20].

A pilot test of the questionnaires was administered to measure the pertinence of the tool; validate it; measure the approach and the understanding of the questions and verify the conformity of the answers with the expected results as recommended by Kathuri \& Pals [21]. A reliability coefficient of 0.90 was realized after analysis which was above the 0.7 recommended by Borg and Galls (1989). The data collection tools were administered by the researcher to smallholder dairy farmers. The interviews were conducted with the help of a trained interpreter since some respondents were illiterate. Data was analyzed by descriptive statistics and the hypothesis tested using Pearson's Correlation; and inference made at 5\% level of significance.

\section{Results and Discussion}

\section{Experience in dairy farming of the respondents}

Table 1: Experience in dairy farming of the respondents.

\begin{tabular}{|c|c|c|c|}
\hline $\begin{array}{c}\text { Experience In } \\
\text { Dairy Farming }\end{array}$ & Frequency (N) & Valid Percent & $\begin{array}{c}\text { Cumulative } \\
\text { Percent }\end{array}$ \\
\hline Below 1 year & 7 & 6.6 & 6.6 \\
\hline 1-5 years & 38 & 35.8 & 42.5 \\
\hline 6-10 years & 28 & 26.4 & 68.9 \\
\hline 11-15 years & 15 & 14.2 & 83 \\
\hline Above 15 years & 18 & 17 & 100 \\
\hline Total & 106 & 100 & \\
\hline
\end{tabular}

Table 1 shows experience in dairy farming of the respondents. Most respondents, 35.8 percent (about one third) had 1-5 years of experience in dairy farming. Other findings were, 26.4 percent had between 6-10 years of experience in dairy farming, 17.0 percent
15 and above years, 14.2 percent had 11-15 years and 6.6 percent had below 1 year of experience in dairy farming. The results of the findings indicate that majority 68.8 percent of the respondents had 10 years and below of experience in dairy farming.

All the respondents were involved in crops production while 7 or $(4.6 \%)$ of the respondents did not practice livestock production (Table 1). Table 1 show that a slightly higher number of men (5 or $5.9 \%$ ) did not keep livestock in their farmers compared to (2 or 3.1 $\%$ ) for female respondents.

\section{Breed of dairy cow kept on farm}

Table 2: Breed of cow kept on farm.

\begin{tabular}{|c|c|c|c|}
\hline & Frequency & Valid Percent & Cumulative Percent \\
\hline Friesian & 27 & 25.5 & 25.5 \\
\hline Ayrshire & 33 & 31.1 & 56.6 \\
\hline Guernsey & 2 & 1.9 & 58.5 \\
\hline Jersey & 4 & 3.8 & 62.3 \\
\hline Zebus & 5 & 4.7 & 100 \\
\hline Cross breeds & 35 & 33 & \\
\hline Total & 106 & 100 & \\
\hline
\end{tabular}

Results in Table 2 show analysis of the breed of dairy cow kept on farms by the respondents. The results indicate that 33.0 percent and 31.1 percent kept crosses and Ayrshire cows respectively. Friesian keepers came third at 25.5 percent and 4.7 percent of the respondents kept zebus. Jerseys and Guernsey were reared by 3.8 and 1.9 percent of the respondents respectively. Most of the respondents (33.0 percent) preferred keeping crosses on farms possibly due to their average management demands and milk production; and relatively high resistance to diseases compared to pure breeds.

\section{Number of years of utilizing milk marketing information through mobile phone}

Table 3: Number of years of utilizing management information from mobile phone.

\begin{tabular}{|c|c|c|c|}
\hline $\begin{array}{c}\text { Years of Utilizing } \\
\text { Information }\end{array}$ & Frequency & Valid Percent & $\begin{array}{c}\text { Cumulative } \\
\text { Percent }\end{array}$ \\
\hline Below 1 year & 15 & 14.2 & 14.2 \\
\hline 1-5 years & 61 & 57.5 & 71.7 \\
\hline 6-10 years & 20 & 18.9 & 90.6 \\
\hline 11-15 years & 8 & 7.5 & 98.1 \\
\hline Above 15 years & 2 & 1.9 & 100 \\
\hline Total & 106 & 100 & \\
\hline
\end{tabular}

Table 3 shows analysis of the number of years the respondents have utilized milk marketing information through mobile phones. The results indicate that 57.5 percent (more than half) had utilized this information for between 1-5 years, 18.9 percent for between 
6-10 years, 14.2 percent of the respondents had utilized milk marketing information through their mobile phones for below 1 year, 7.5 percent for between 11-15 years and 1.9 percent had utilized milk marketing information through their phones for over 15 years. This follows that majority 57.5 percent of the population had utilized milk marketing information through mobile phones for between 1-5 years. These results agree with Keyser 22, who found out that access to dairy extension services increased utilization of milk marketing information among small-scale farmers which in turn increased milk yield by ten (10) percent.

\section{Management information providers through mobile phones}

Table 4: Management information providers through mobile phones.

\begin{tabular}{|c|c|c|c|}
\hline $\begin{array}{c}\text { Information Providers } \\
\text { from Mobile Phones }\end{array}$ & Frequency & $\begin{array}{c}\text { Valid } \\
\text { Percent }\end{array}$ & $\begin{array}{c}\text { Cumulative } \\
\text { Percent }\end{array}$ \\
\hline Government extension & 68 & 64.2 & 64.2 \\
\hline Milk cooperative society & 4 & 3.8 & 67.9 \\
\hline Private companies & 16 & 15.1 & 83 \\
\hline NGOs/FBOs & 5 & 4.7 & 87.7 \\
\hline Radio station & 8 & 7.5 & 95.3 \\
\hline Research stations & 4 & 3.8 & 99.1 \\
\hline Other (specify) & 1 & 0.9 & 100 \\
\hline Total & 106 & 100 & \\
\hline
\end{tabular}

The main milk marketing information providers through mobile phones are shown in Table 4. The results indicate that 64.2 percent of the respondents got milk marketing information from government extension service providers via their mobile phones and 15.1 percent from private companies. Radio stations came third at 7.5 percent, 4.7 percent from NGOs/FBOs, 3.8 percent from milk co-operative societies, 3.8 percent from research stations and 0.9 percent were provided milk marketing information from mobile phones by others who included neighbors. The implication is that government extension service providers were the most popular source of milk marketing information through mobile phones. Therefore government service providers can effectively be used to convey milk marketing information to the farmers via their mobile phones in order to enhance dairy production.

\section{Utilizing various milk marketing information through mobile phones}

With regard to utilizing milk marketing information, about a half of the respondents, $43.4 \%$ percent, utilized milk prices information as their preferred milk marketing information from mobile phones. Slightly more than one third, 35.8 percent utilized information on place to sell milk, 8.5 percent on home milk value addition, 6.6 percent other forms and 5.7 percent of the respondents utilized milk advertisement as their preferred milk marketing information through mobile phones. Their responses are presented in Table 5.
Table 5: Utilizing various milk marketing information through mobile phones.

\begin{tabular}{|c|c|c|c|}
\hline Variable & Labels & Frequency & Percent \\
\hline \multirow{6}{*}{$\begin{array}{l}\text { Milk marketing } \\
\text { information utilized } \\
\text { from mobile phones }\end{array}$} & $\begin{array}{l}\text { Place to sell } \\
\text { milk }\end{array}$ & 38 & 35.8 \\
\hline & Milk prices & 46 & 43.4 \\
\hline & $\begin{array}{c}\text { Home milk } \\
\text { value addition }\end{array}$ & 9 & 8.5 \\
\hline & $\begin{array}{c}\text { Milk } \\
\text { advertisement }\end{array}$ & 6 & 5.7 \\
\hline & $\begin{array}{c}\text { Other } \\
\text { (specify)-- }\end{array}$ & 7 & 6.6 \\
\hline & Total & 106 & 100 \\
\hline
\end{tabular}

The findings of the study are in agreement with the work by IFAD [4], which found out that smallholder dairy farmers need essential milk marketing information which may lead to milk value addition that may enhance access to better milk prices hence increased milk yield.

\section{Whether utilizing milk marketing information through mobile phones could increase milk yield}

With regard to whether utilizing milk marketing information through mobile phones could increase milk yield, 84.9 percent said it could increase milk yield, 9.4 percent said it could not and $5.7 \%$ did not know whether utilizing milk marketing information from mobile phones could increase milk yield. Overall, majority of the respondents 84.9 percent agreed that utilizing milk marketing information through mobile phones could lead to increased milk yield as shown in Table 6.

Table 6: Whether utilizing milk marketing information through mobile phones could increase milk yield.

\begin{tabular}{|c|c|c|c|}
\hline Variable & Labels & Frequency & Percent \\
\hline $\begin{array}{c}\text { Opinion on whether } \\
\text { utilizing milk marketing } \\
\text { information through } \\
\text { mobile phones could } \\
\text { increase milk yield }\end{array}$ & Yes & 90 & 84.9 \\
\hline & No & 10 & 9.4 \\
\hline & Do not know & 6 & 5.7 \\
\hline & Total & $\mathbf{1 0 6}$ & $\mathbf{1 0 0}$ \\
\hline
\end{tabular}

This implies that smallholder dairy farmers who accessed milk marketing information through their mobile phones were more likely to utilize the same leading to better dairy cow management hence increased milk production due to better prices. The findings are in line with a study done by IFAD [5], which indicated that adequate access and utilization of milk marketing information had a positive impact on milk production in Kenya. 
Hypothesis: Utilizing milk marketing information through mobile phones has no statistically significant influence on milk yield among smallholder dairy farmers in Njoro Sub-County

Table 7: Influence of utilizing milk marketing information on milk yield.

\begin{tabular}{|c|c|c|c|}
\hline & & $\begin{array}{l}\text { Milk Marketing } \\
\text { Information } \\
\text { Utilized } \\
\text { through Mobile } \\
\text { Phone in } \\
\text { KES used on } \\
\text { Airtime Per } \\
\text { Day }\end{array}$ & $\begin{array}{l}\text { Milk Yield in } \\
\text { Litres Per Cow } \\
\text { Per Day after } \\
\text { Utilizing Milk } \\
\text { Marketing } \\
\text { Information }\end{array}$ \\
\hline \multirow{3}{*}{$\begin{array}{l}\text { Milk marketing } \\
\text { information } \\
\text { utilized through } \\
\text { mobile phone } \\
\text { in KES used on } \\
\text { airtime per day }\end{array}$} & $\begin{array}{l}\text { Pearson } \\
\text { Correlation }\end{array}$ & 1 & $.557^{* *}$ \\
\hline & Sig. (2-tailed) & . & 0 \\
\hline & $\mathrm{N}$ & 106 & 106 \\
\hline \multirow{3}{*}{$\begin{array}{l}\text { Milk yield in } \\
\text { litres per cow } \\
\text { per day after } \\
\text { utilizing milk } \\
\text { marketing } \\
\text { information }\end{array}$} & $\begin{array}{l}\text { Pearson } \\
\text { Correlation }\end{array}$ & $.557^{* *}$ & 1 \\
\hline & Sig. (2-tailed) & 0 & . \\
\hline & $\mathrm{N}$ & 106 & 106 \\
\hline
\end{tabular}

Pearson's correlation was used to test the influence of utilizing milk marketing information through mobile phones on milk yield as summarized in Table 7. The results indicated that the Sig. (2-Tailed) value of 0.001 is less than 0.05 at the 0.05 (5\%) significance level. The Pearson Correlation value $(+0.557)$ is significant at $0.05(\mathrm{p}<0.05)$, implying that there is a significant strong positive correlation between utilizing milk marketing information through mobile phones and milk yield $(r=0.557 ; \mathrm{p}<0.05)$. Smallholder dairy farmers who utilized milk marketing information through their mobile phones had a moderate increase in milk yield.

Based on the data, the study rejected the null hypothesis and concludes that there is a positive correlation between utilizing milk marketing information through mobile phones and milk yield among smallholder dairy farmers in Njoro Sub-County. The findings about the influence of utilizing milk marketing information through mobile phones on milk yield among smallholder dairy farmers are in line with the work of Kamau [23], Namaga [24]. Kamau [23] for example, found out that mobile phones usage in rural Kenya for business clearly supports smallholder dairy farmers in marketing and selling their milk thereby increasing their income levels through increased milk yields [25-27].

\section{Conclusion}

The results from this study revealed that utilizing milk marketing information through mobile phones by smallholder dairy farmers was found to have a positive and significant influence on milk yield $(\mathrm{r}=0.557 ; \mathrm{p}<0.05)$. Utilizing milk marketing information through mobile phones by smallholder dairy farmers had a statistically significant correlation with milk yield since the Sig. (2-Tailed) value $(0.001)$ is less than 0.05 . Based on the data, the study rejected the null hypothesis and concludes that there is a positive correlation between utilizing milk marketing information through mobile phones and milk yield among smallholder dairy farmers in Njoro Sub-County.

\section{Recommendation}

Milk yield among smallholder dairy farmers has been found to be influenced by utilization of milk marketing information among other factors. From the findings and conclusion of the study, it was therefore recommended that efforts should be made in Njoro Sub-County to encourage smallholder dairy farmers to utilize milk marketing information through mobile phones in order to improve milk yield.

\section{References}

1. FAO (2007) Food and agricultural organization report.

2. IFAD (2012) Small Holder Dairy Commercialization Programme Report, IFAD and GOK Report, Republic of Kenya, pp. 1-44.

3. Gichungu G (2009) Role of small and medium enterprises (SMEs) in sustainable dairy development in Kenya. Ministry of Trade and Industry report, Government Printer, Nairobi, Kenya.

4. MOLD (2011b) Provincial Director of Livestock Production. Rift Valley Annual Report, Published by government press, Kenya, pp. 33-41.

5. GoK (2007) Kenya review and appraisal of the final report on the implementation of the Beijing platform of action (1994-2004). Government Printer, Nairobi, Kenya.

6. MOLD (2011c) Director of Livestock Production Annual Report. Published by government press, Nairobi, Kenya, pp. 13-17.

7. Walubengo D (2007) Community-led action to use forestry in building resilience toclimate change: a Kenyan case study Njoro Division, Nakuru District, Kenya. Forest Action, pp. 1-18.

8. Arya JC, Jacobs IB (1978) Mobile phones and economic development in Africa. Journal of Economic Perspectives 24(3): 207-232.

9. Ombati JM (2006) A study of competitiveness in monitoring and evaluation needed by field level extension staff. Kenya, pp. 32-34.

10. Mold (2011) District Livestock Production Officer, Annual Report. Unpublished report, Njoro, Kenya, pp. 48-51.

11. FAO (2011) Enhancing livestock production to support vulnerable populations affected by volatile food price Report. Europe aid, pp. 1-2.

12. Mugenda MO, Mugenda GA (2003) Research Methods: Quantitative and Qualitative Approaches., African Center for Technology Studies (ACTS) Press, Nairobi, Kenya, pp. 1-233.

13. Omiti J, Wanyoike F, Staal S, Delgado C, Njoroge L (2006) Will SmallScale Dairy Producers in Kenya Disappear Due to Economies of Scale in Production? Contributed paper prepared for presentation at the International Association of Agricultural Economists Conference, Gold Coast, Australia, p. 1.

14. Namaga N (2012) Mobile technology unlocks dairy farming potential. ILRI, India.

15. Kamau G (2012) Uplifting Poor Smallholder Farmers in Kenya through the Mobile Phone. Nairobi: ACTS Press, pp. 1-10.

16. Calpi GB (2005) Livestock Environment and Development in Watersheds. Intel-corporation India Programme Delegation Report Series 1. Viking, New York, USA, pp. 209-214.

17. Mumbi K (2012) Mobile phones usage in rural Kenya for business. ACTS Press, Nairobi, Kenya. 
18. Mold (2010) District Livestock Production Officer, Annual Report. Unpublished report, Njoro, Kenya.

19. Keyser J (2009) Competitive dairy development and challenges in east and southern Africa. Study undertaken for the World Bank. Washington DC and the University of Guelph, Ontario, Canada, pp. 286-289.

20. KNBS (2009) Population census of 2009. Published by government press, Kenya.

21. CCK (2012) Quarterly Sector Statistics Report 3 Quarter Jan-Mar 2010/2011. Kenya.

22. NAFIS (2011) Innovative dairy technologies and advantages of mobile phones use. Kenya.
23. ITU (2012) Mobile world congress 2012 coverage.

24. Kathuri P (1993) Introduction to Educational Research. Acts Press, Nairobi, Kenya.

25. Nassiuma DK (2000) Survey Sampling: Theory and Methods. University of Nairobi Press, Kenya, p. 268.

26. Wambua J (2012) Grow-connect-sell: The wealth formula for smallscale farmers. M-farm limited, kenya.

27. Gamba P (2006) Beef and Dairy Cattle Improvement Services: a Policy Perspective; Tegemeo Institute of Agricultural Policy and Development, Egerton University, Kenya, pp. 22-25.

\section{Your next submission with Juniper Publishers will reach you the below assets}

- Quality Editorial service

- Swift Peer Review

- Reprints availability

- E-prints Service

- Manuscript Podcast for convenient understanding

- Global attainment for your research

- Manuscript accessibility in different formats

( Pdf, E-pub, Full Text, Audio)

- Unceasing customer service

Track the below URL for one-step submission https://juniperpublishers.com/online-submission.php 